\title{
Maisyah and Culture Of Work As Motivation For Work, Analysis in The General Elections Commission Secretariat (KPU) Musi Rawas Regency
}

\begin{tabular}{|c|c|}
\hline \multicolumn{2}{|c|}{$\begin{array}{c}\text { Supriadi, Pasiska } \\
\text { STAI Bumi Silampari, Lubuklinggau, Sout Sumatera, Indonesia } \\
\text { supriadispmm80@gmail.com, pasiskaptg@gmail.com }\end{array}$} \\
\hline & Abstrak \\
\hline $\begin{array}{l}\text { Article History } \\
\text { Received :13-02-2020 } \\
\text { Revised :18-02-2020 } \\
\text { Accepted :29-02-2020 } \\
\text { Keywords: } \\
\text { Maisyah, Culture of } \\
\text { Work, work } \\
\text { motivation, }\end{array}$ & $\begin{array}{l}\text { This study aims to determine the effect of Maisyah and } \\
\text { Culture of Work toward the Work Motivation Employee } \\
\text { of General Elections Commissionof Musi Rawas } \\
\text { regency. This study involved } 4 \text { respondents, all of which } \\
\text { were employees of General Elections Commissionof } \\
\text { Musi Rawas regency. To collect the data, this study } \\
\text { used a set of questionnaires and the respond given by } \\
\text { the sample was analyzed by (1) average score, (2) } \\
\text { multiple linearity regression, (3)determination } \\
\text { coefficient, (4) partial t-test and F test techniques.Based } \\
\text { on the result analysis, it was found out that (1) there is } \\
\text { a positive correlation between independent variables } \\
\text { with the dependent variables, (2) the magnitude of } \\
\text { independent variables influence toward the dependent } \\
\text { variable was } 40.40 \% \text { and (3) the partial t-test and F- } \\
\text { test result showed higher coefficient values than those } \\
\text { on the critical value of the t and F tables. Based on } \\
\text { these findings, it was concluded that maisyah and } \\
\text { culture of work, separately and simultaneously, } \\
\text { influenced the work motivation employee of General } \\
\text { Elections Commission of Musi Rawas regency. }\end{array}$ \\
\hline
\end{tabular}

\section{Pendahuluan}

Sebagai salah satu kabupaten yang baru dilakukan pemekaran wilayah otonomi baru, Kabupaten Musi Rawas menjadi Kabupaten Musi Rawas Utara berdasarkan dengan Undang-Undang nomor 6 tahun 2013 (https://jdih.kpu.go.id/ diakses tanggal 10 Juni 2016), Kabupaten Musi Rawas Provinsi Sumatera Selatan berusaha terus memperbaiki diri untuk menciptakan pemerintahan yang mendapat capaian "good governance". Salah satu bagian yang memiliki peran penting dalam upaya mempersiapkan kondisi tersebut harus didukung semua elemen/lembaga/dinas terkait, yaitu salah satunya Komisi Pemilihan Umum (KPU) Kabupaten Musi Rawas.

Komisi Pemilihan Umum (KPU) Kabupaten Musi Rawas sebagai salah satu penyelenggara pemilihan umum dan pemilihan kepala daerah senantiasa melakukan upaya peningkatan kinerja. Kegiatan yang dilakukan memperhatikan kemampuan organisasi melaksanakan tugas dan tanggungjawabnya. Hanya saja, berdasarkan hasil pengamatan sehari-hari dapat dideskripsikan bahwa, kinerja aparatur KPU Kabupaten Musi Rawas belum sesuai dengan harapan. Hal tersebut dapat dilihat dari aspek kualitas kinerja pegawai belum optimal, tingkat 
konsistensi, kebijakan program belum sesuai dengan tugas dan fungsinya. Sedangkan dari aspek kuantitas kinerja pegawai belum menunjukkan capaian kerja yang sesuai dengan harapan serta dari aspek waktu penyelesaian suatu pekerjaan oleh pegawai terlihat bahwa ketersediaan waktu yang ada masih belum dapat dimanfaatkan dengan maksimal atau dengan kata lain dapat dikatakan penyelesaiannya tidak sesuai dengan waktu yang telah ditentukan oleh lembaga/organisasi. Tuntutan perubahan terhadap sistem nilai dan budaya kerja dalam penyelenggaraan pemerintahan sangat diperlukan saat ini. Penyelenggaraan otonomi daerah menuntut nilai dasar agar dapat mengakomodasikan kebutuhan yang berorientasi kepada aspirasi masyarakat dengan prinsip-prinsip demokratis, peran serta, pemerataan dan berkeadilan. Kondisi tersebut menuntut adanya kerangka pikir yang terstruktur untuk memberdayakan fungsi publik agar sesuai dengan tuntutan perkembangan politik, sosial ekonomi, dan budaya. Karena itu peningkatan budaya dan etos kerja yang berorientasi kepada pencapaian hasil sangat diperlukan serta pertanggungjawaban berdasarkan nilai-nilai akuntabilitas menuju good governance sesuai dengan harapan.

Berdasarkan Peraturan Komisi Pemilihan Umum Nomor: 22 Tahun 2008 tentang Susunan Organisasi dan Tata Kerja Sekretariat Komisi Pemilihan Umum (KPU) merupakan salah satu bagian yang mempunyai tugas melaksanakan urusan teknis Pemilu dan hubungan partisipasi masyarakat (https://jdih.kpu.go.id/ diakses tanggal 10 Juni 2016), Komisi Pemilihan Umum (KPU) Kabupaten Musi Rawas merupakan pelaksana operasional yang mempunyai tugas melaksanakan sebagian tugas teknis operasional Pemilu yang. KPU Kabupaten Musi Rawas melakukan berbagai upaya peningkatan kinerja, salah satunya dengan memperhatikan kemampuan sumber daya manusia dalam melaksanakan tugas.

Selain memiliki tugas pokok, melakukan kegiatan mengumpulkan dan mengelola bahan teknis penyelenggaraan Pemilu dan Pemilukada, Komisi Pemilihan Umum (KPU) Kabupaten Musi Rawas melaksanakan semua tugas tersebut mulai dari perencanaan, pelaksanaan sampai dengan pertanggungjawaban akhir, tentu sangat diperlukan motivasi kerja yang tinggi dari semua pegawai Komisi Pemilihan Umum Kabupaten Musi Rawas. Motivasi adalah perilaku yang bekerja dalam usaha memenuhi kebutuhan-kebutuhan yang diinginkan (Irham Fahmi, 2014; 190). Motivasi juga mempersoalkan upaya caranya mendorong etos kerja bawahan, agar mereka mau bekerja keras dengan memberikan semua kemampuan dan keterampilannya untuk mewujudkan tujuan. Motivasi penting karena dengan motivasi diharapkan setiap individu mau bekerja keras dan antusias untuk mecapai produktivitas kerja (Hasibuan, 2014; 216)

Dari latar belakang masalah diatas, paling tidak ada 7 (tujuh) masalah yang dapat diidentifikasi, yaitu: (1) Belum optimalnya sumber daya aparatur yang ada, karena masih kurangnya aparatur untuk mengisi bagian-bagian yang ada, sehingga layanan peningkatan kompetensi belum menyentuh peningkatan kompetensi para komisioner, Sekretaris dan Kasubbag, dikarenakan tingkat disiplin aparatur yang masih rendah. (2) Sumber Daya manusia masih kurang, sementara wilayah kerja sangat luas yaitu saat ini menjadi 14 kecamatan dengan jumlah desa 199 desa/kelurahan yang semula 21 kecamatan dan hanya dilayani oleh 15 orang PNS dan 17 orang pegawai Honor. (3) Masih terdapatnya aparatur KPU yang belum memahami tugas pokok dan fungsinya. (4) Belum tersedianya gedung kantor secara permanen, perangkat lunak maupun perangkat keras serta sarana dan 
prasarana perkantoran yang masih sangat minim. Sarana dan Prasarana yang masih minim tersebut, mulai dari fasilitas kantor misalnya yang tidak memiliki saluran telepon dan mesin fax untuk surat menyurat formal kantor, ruang kantor yang berukuran sempit dimana ruang dengan ukuran $3 \times 4$ harus dihuni oleh 4 orang SDM beserta berkas-berkasnya, ditambah lagi ada ruangan yang menjadi satu untuk beberapa bagian. (5) Peraturan yang menjadi dasar untuk melakukan pekerjaan terkadang sangat lambat dijadikan Undang-Undang.Sebagai contoh, ketika tahapan Pilkada serentak tahun 2015 dimulai tanggal 19 April untuk pelaksanaannya tetapi Peraturan baru selesai dan diterima oleh KPU Kabupaten/Kota pada tanggal 16 April 2016. (6) Maisyah yang diperoleh bervariasi dan cenderung belum proporsional sesuai dengan tugas pokok dan fungsinya dan membuat perbedaan dalam motivasi kerja. (7) Budaya bekerja di KPU Kabupaten Musi Rawas masih belum baik terutama jika dihubungkan dengan motivasi kerja.

Berdasarkan identifikasi masalah yang telah diulas tersebut, maka saya sebagai peneliti ingin melakukan penelitian dengan judul "Maisyah Dan Budaya Bekerja Sebagai Motivasi Kerja, Analisis di Sekretariat Komisi Pemilihan Umum (KPU) Kabupaten Musi Rawas Periode 2016". Memang pernyataan pada identifikasi masalah merupakan fenomena yang terjadi, namun demikian diantara banyaknya fenomena, maka penelitian ini hanya akan meneliti sebagian yang dianggap paling penting. Implementasi penelitian ini hanya dibatasi pada "Maisyah Dan Budaya Bekerja Sebagai Motivasi Kerja, Analisis di Sekretariat Komisi Pemilihan Umum (KPU) Kabupaten Musi Rawas Periode 2016”.

\section{Metode Penelitian}

Metode Penelitian bila dilihat dari landasan filsafat, data dan analisisnya dapat dikelompokkan menjadi tiga yaitu; metode penelitian kuantitatif, metode penelitian kualitatif, dan metode penelitian kombinasi (Sugiyono, 2007) dalam Bahri, Syamsul (2014: 3). Mengingat berbagai pertimbangan yang ada tersebut, Peneliti memutuskan untuk melaksanakan penelitian ini menggunakan metode kuantitatif.

\section{Obyek dan Lokasi Penelitian}

Objek penelitian ini adalah Pengaruh Kompensasi dan Budaya Organisasi Terhadap Motivasi Kerja Pegawai di Sekretariat Komisi Pemilihan Umum (KPU) Kabupaten Musi Rawas.

\section{Lokasi Penelitian (Locus)}

Lokasi penelitian adalah di Kantor Komisi Pemilihan umum (KPU) yang terletak di Kecamatan Muara Beliti, ibu kota Kabupaten Musi Rawas Provinsi Sumatera Selatan.

\section{Populasi dan Sampel}

Adapun populasi dalam penelitian ini adalah seluruh karyawan Komisi Pemilihan Umum (KPU) Kabupaten Musi Rawas yang berjumlah 40 orang.

\section{Sampel Penelitian}


Sampel adalah sebagian atau wakil populasi yang diteliti (Arikunto, 2010 : 174). Jika jumlah populasinya kurang dari 100 orang, maka jumlah sampelnya diambil secara keseluruhan, tetapi jika populasinya lebih besar dari 100 orang, maka bisa diambil $10-15 \%$ dari jumlah populasinya. Karena jumlah populasi dalam penelitian ini kurang dari 100 orang maka populasi diambil semua sebagai sampel penelitian (Arikunto, 2004: 104).

\section{Instrumen Penelitian}

Instrumen pengumpulan data yang digunakan dalam penelitian ini adalah metode angket atau kuesioner. Kuisioner adalah sejumlah pertanyaan tertulis yang digunakan untuk memperoleh informasi dari responden dalam arti laporan tentang pribadinya, atau hal-hal yang ia ketahui. Kuesioner dipakai untuk menyebut metode maupun instrumen. Jadi dalam menggunakan metode angket atau kuesioner instrumen yang dipakai adalah angket atau kuesioner (Arikunto, 2010: 194). Dalam penelitian ini kuesioner terdiri atas pernyataan yang didasarkan pada indikator masing-masing variabel dan setiap item pertanyaan diberikan alternatif jawaban berupa pernyataan "Sangat Setuju", "Setuju", "Tidak Berpendapat", "Kurang Setuju" dan "Tidak Setuju". Masing - masing pernyataan diberikan skor 5 untuk "Sangat Setuju", 4 untuk "Setuju", 3 untuk "Tidak Berpendapat", 2 untuk "Tidak Setuju" dan 1 untuk "Sangat Tidak Setuju".

\section{Uji Ketepatan/ Validitas dan Reliabilitas Instrumen/Uji Konsistensi}

Uji validitas/ Ketepatan ini diperoleh dengan cara mengkorelasi setiap skor indikator dengan dengan total skor indikator variabel, kemudian hasil korelasi dibandingkan dengan nilai kritis pada tarap signifikan 0,05. analisis item, pada setiap butir pertanyaan dikorelasikan dengan total nilai seluruh butir pertanyaan untuk suatu variabel dengan menggunakan rumus korelasi Pearson Product Moment. Syarat minimum untuk dianggap valid adalah nilai $\mathrm{r}$ hitung $>$ dari nilai $\mathrm{r}$ tabel (Sugiyono, 2007: 138). Adapun perhitungan korelasi product moment, dengan rumus seperti yang dikemukakan oleh Arikunto (2004: 220);

$$
r_{x y}=\frac{n \Sigma X_{i} Y_{i}-\left(\Sigma X_{i}\right)\left(\Sigma Y_{i}\right)}{\sqrt{\left(n \Sigma X_{i}^{2}-\left(\Sigma X_{i}\right)^{2} \prod^{n} \sum^{n} Y_{i}^{2}-\left(\Sigma Y_{i}\right)^{2}\right)}}
$$

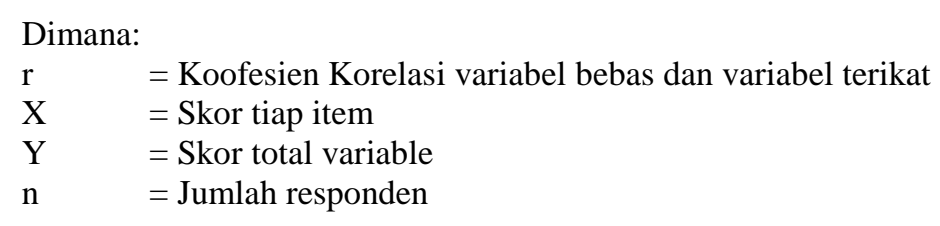

\section{Uji Reliabilitas/ Uji Konsistensi}

Uji reliabilitas/ Uji Konsistensi digunakan teknik Alpha Cronbach, dimana suatu instrumen dapat dikatakan handal (reliabel) bila memiliki koefisien Alpha Cronbach sebesar 0,6 atau lebih (Menurut Sugiyono, 2007: 225). Pada penelitian ini perhitungan reliabilitas menggunakan rumus alpha sebagai berikut:

$$
r^{11}=\left[\frac{k}{k-1}\right]\left[\frac{1-\sum \alpha b 2}{\alpha t 2}\right]
$$

Dimana: 


$$
\begin{aligned}
\alpha & =\frac{\sum X^{2}-\frac{\sum X^{2}}{N}}{N} \\
\mathrm{r}_{11} & =\text { Reliabilitas instrumen } \\
\mathrm{k} & =\text { Banyaknya butir pertanyaan } \\
\sigma \mathrm{b} 2 & =\text { Jumlah varians butir } \\
\sigma \mathrm{l} 2 & =\text { Jumlah varians table }
\end{aligned}
$$

\section{Teknik Analisis Data}

\section{Skoring}

Skoring dalam penelitian ini adalah skoring rata - rata untuk masing masing responden, skoring rata - rata item dan skoring rata - rata indikator dan variabel. Dengan rumus(Sugiyono, 2007):

\section{Skoring Rata - rata Individu}

$$
\text { Skor Rata }- \text { rata Individu }=\frac{\text { Total Nilai per Individu }}{\text { Jumlah Item }}
$$

\section{Skor Rata - rata Item}

$$
\text { Skor Rata }- \text { Rata Item }=\frac{\text { Total Nilai Item }}{\text { Jumlah Responden }}
$$

\section{Skor Rata - rata Indikator}

$$
\text { Skor Rata }- \text { rata Indikator }=\frac{\text { Total Nilai Indikator }}{\text { Jumlah Item } x \text { Jumlah Responden }}
$$

\section{Skor Rata - Rata Variabel}

$$
\text { Skor Rata }- \text { rata Variabel }=\frac{\text { Total Nilai Variabel }}{\text { Jumlah Item } x \text { Jumlah Responden }}
$$

Untuk menentukan kualifikasi kompensasi, budaya organisasi dan tingkat motivasi kerja pegawai, hasil skor rata-rata tersebut dimasukan ke dalam tabel skala kualifikasi. Penentuan skala kualifikasi menggunakan rumus sebagai berikut:

$$
R S K=\frac{N T i A j-N T r A j}{J A j}
$$

Keterangan:

RSK = Rentang Skor Kualifikasi

NTiAj = Nilai Tertinggi Alternatif Jawaban

$\mathrm{NTrAj}=$ Nilai Terendah Alternatif Jawaban

$\mathrm{JAj} \quad=$ Jumlah Alternatif Jawaban

Berdasarkan rumus diatas dapat dijelaskan bahwa nilai tertinggi alternatif jawaban yang diberikan adalah 5, sedangkan nilai terendah alternatif jawaban adalah 1 dan jumlah alternatif jawaban adalah 5. Dengan demikian maka rentang skor kualifikasi sebesar 0,80. Berdasarkan hasil perhitungan ini, ditentukan tabel skala kualifikasi sebagai berikut:

Tabel 3.2 


\begin{tabular}{cccc}
\hline \multirow{2}{*}{ Rentang Skor } & Kompensasi Kerja & Budaya Organisasi & $\begin{array}{c}\text { Motivasi Kerja } \\
\text { Pegawai }\end{array}$ \\
\cline { 2 - 4 } & Rendah & Rendah & Rendah \\
\hline $0,00-1,80$ & Kurang Tinggi & Kurang Baik & Kurang Tinggi \\
$1,81-2,60$ & Cukup Tinggi & Cukup Baik & Cukup Tinggi \\
$2,61-3,40$ & Tinggi & Baik & Tinggi \\
$3,41-4,20$ & Sangat Tinggi & Sangat Baik & Sangat Tinggi \\
$4,21-5,00$ & & & \\
\hline
\end{tabular}

\section{Analisis Regresi Berganda}

Rumus analisis regersi berganda adalah:

$\mathrm{Y}=\mathrm{a}+\mathrm{b}_{1} \mathrm{X}_{1}+\mathrm{b}_{2} \mathrm{X}_{2} \quad$ (Sugiyono, 2007: 277)

Dimana:

$\mathrm{Y} \quad=$ Motivasi kerja Pegawai

$\mathrm{X}_{1} \quad=$ Kompensasi Kerja

$\mathrm{X}_{2}$ = Budaya Organisasi

a $\quad$ Konstanta

$b_{1}, b_{2}=$ Koofesien Regresi

\section{Koefisien Determinasi}

Koefisein determinasi digunakan untuk mengetahui persentase pengaruh semua variabel bebas terhadap variabel terikat dengan rumus sebagai berikut (Sugiyono, 2007:280):

$$
\begin{aligned}
& R^{2}=\frac{b 1 \sum X_{1} Y+b 2 \sum X_{2} Y}{\sum Y^{2}} \\
& \text { Dimana: } \\
& \mathrm{R}^{2}=\text { Koefisiensi Determinasi } \\
& \mathrm{b} 1 . \mathrm{b} 2=\text { Koefisien Regresi } \\
& \mathrm{X} 1=\text { Kompensasi Kerja } \\
& \mathrm{X} 2 \quad=\text { Budaya Organisasi } \\
& \mathrm{Y}=\text { Motivasi kerja Pegawai }
\end{aligned}
$$

\section{Uji F (uji simultan)}

Untuk mengetahui signifikan pengaruh kompensasi kerja dan budaya organisasi secara terpisah terhadap motivasi kerja pegawai Komisi Pemilihan Umum Kabupaten Musi Rawas digunakan rumus uji $\mathrm{F}$ sebagai berikut (Sugiyono, 2007: 235):

$$
\begin{aligned}
& \mathbf{F}_{\text {hitung }}= \frac{R^{2} / k}{1-R^{2} /(n-k-1)} \\
& \text { Dimana: } \\
& \mathrm{R}^{2} \quad \text { Koefisien korelasi berganda. } \\
& \mathrm{k} \quad \text { = Jumlah variabel independent. } \\
& \mathrm{n} \quad=\text { Jumlah anggota sampel. }
\end{aligned}
$$

\section{Uji t (uji parsial)}


Guna mengetahui signifikansi dari variabel maisyah dan budaya kerja secara terpisah terhadap motivasi kerja pegawai Komisi Pemilihan Umum Kabupaten Musi Rawas digunakan uji t dengan rumus sebagai berikut:

$$
t_{\text {hitung }}=\frac{r \sqrt{n-2}}{\sqrt{1-r^{2}}}
$$

Dimana:

$\mathrm{t}=$ nilai $\mathrm{t}_{\text {hitung }}$

$\mathrm{n}=$ jumlah responden

$\mathrm{r}=$ koefisien korelasi hasil $\mathrm{r}$ hitung

Prosedur uji hipotesis yang digunakan adalah sebagai berikut:

\section{Pembahasan}

\section{Hasil Penelitian}

\section{Deskripsi Responden Penelitian}

\section{a. Jenis Kelamin Responden}

Berikut adalah deskripsi data jenis kelamin responden:

Tabel 4.1

Jenis Kelamin Responden

\begin{tabular}{|ll|r|r|r|r|}
\hline & & Frequency & $\begin{array}{c}\text { Percen } \\
\mathrm{t}\end{array}$ & $\begin{array}{c}\text { Valid } \\
\text { Percent }\end{array}$ & $\begin{array}{c}\text { Cumulative } \\
\text { Percent }\end{array}$ \\
\hline Valid & Laki-Laki & 18 & 45,0 & 45,0 & 45,0 \\
& Perempua & 22 & 55,0 & 55,0 & 100,0 \\
& $\mathrm{n}$ & 40 & 100,0 & 100,0 & \\
& Total & &
\end{tabular}

(Sumber: Hasil Kuesioner, data diolah 2016)

\section{Gambar 4. 1}

Persentase Jenis Kelamin Responden

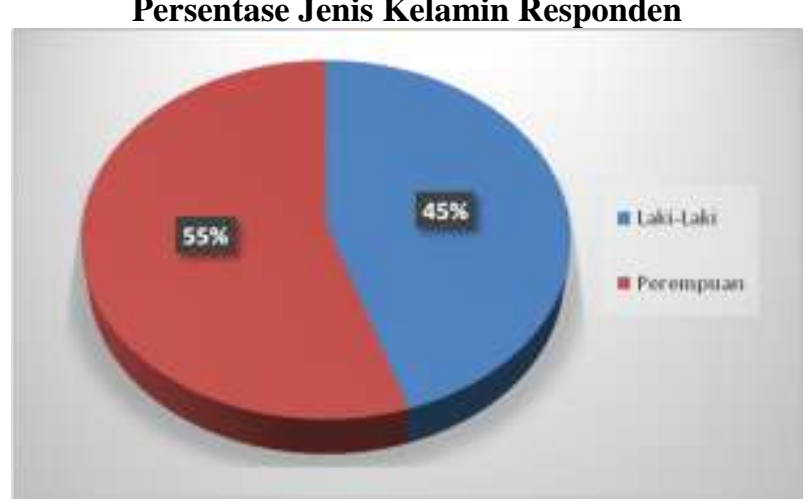

(Sumber: olahan penelitian 2016)

Berdasarkan pada Tabel 4.1 dan Gambar 4.1 dapat dijelaskan jumlah respondendi sekretariat Komisi Pemilihan Umum Kabupaten Musi Rawas berjenis kelamin laki-laki sebanyak 18 orang $(45,00 \%)$ dan perempuan sebanyak 22 orang $(55,00 \%)$.

\section{b. Usia Responden}

Berikut adalah deskripsi data usiaresponden: 
Tabel 4.2. Usia Responden

\begin{tabular}{|c|c|c|c|c|c|}
\hline & & Frequency & Percent & $\begin{array}{l}\text { Valid } \\
\text { Percent }\end{array}$ & $\begin{array}{c}\text { Cumulative } \\
\text { Percent }\end{array}$ \\
\hline \multirow[t]{5}{*}{ Valid } & 18-22 tahun & 6 & 15,0 & 15,0 & 15,0 \\
\hline & 22-27 tahun & 4 & 10,0 & 10,0 & 25,0 \\
\hline & 27-32 tahun & 8 & 20,0 & 20,0 & 45,0 \\
\hline & $\begin{array}{l}\text { di atas } 32 \\
\text { tahun }\end{array}$ & 22 & 55,0 & 55,0 & 100,0 \\
\hline & Total & 40 & 100,0 & 100,0 & \\
\hline
\end{tabular}

(Sumber: olahan penelitian 2016)

Gambar 4.2

Persentase Usia Responden

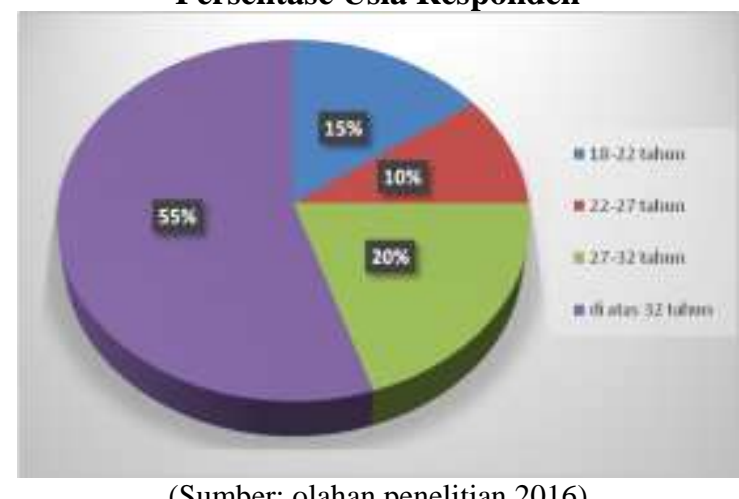

(Sumber: olahan penelitian 2016)

Berdasarkan Tabel 4.2 dan Gambar 4.2 dapat dijelaskan bahwa responden terbanyak berasal dari kelompok usia diatas 32 tahun yaitu 23 orang $(57,50 \%)$. Sebagian besar kelompok ini adalah staf. Responden paling sedikit berasal dari kelompok usia28 - 32 tahun(5,00 $\%)$. Kelompok usia18 - 22 tahunsebanyak 6 orang $(15,00 \%)$, dan kelompok usia22 - 27 tahunsebanyak 9 orang $(22,50 \%)$.

\section{c. PendidikanTerakhir Responden}

Berikut adalah deskripsi Pendidikan terakhir responden

Tabel 4.3

Pendidikan Terakhir Responden

\begin{tabular}{|ll|r|r|r|r|}
\hline & Frequency & Percent & $\begin{array}{c}\text { Valid } \\
\text { Percent }\end{array}$ & $\begin{array}{c}\text { Cumulative } \\
\text { Percent }\end{array}$ \\
\hline Valid & SMA & 12 & 30,0 & 30,0 & 30,0 \\
& 24 & 60,0 & 60,0 & 90,0 \\
& S1/sarjana & 4 & 10,0 & 10,0 & 100,0 \\
lainnya & 40 & 100,0 & 100,0 & \\
(D1/D2/s2/s3) & 40 & \\
Total & &
\end{tabular}

(Sumber: Hasil Kuesioner, data diolah 2016)

Gambar 4.3

Persentase Pendidikan Terakhir Responden 


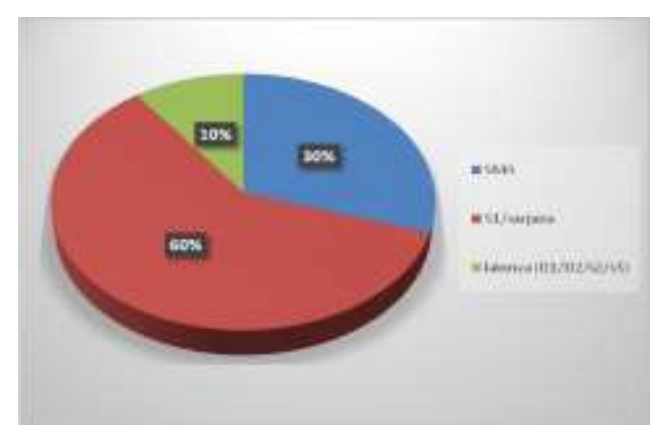

(Sumber: olahan penelitian 2016)

Berdasarkan Tabel 4.3 dan Gambar 4.3 dapat dijelaskan bahwa responden terbanyak memiliki tingkat pendidikan terakhir adalah sarjana/Strata Satu yaitu sebanyak 24 orang $(60,00 \%)$. Sedangkan untuk responden yang memiliki pendidikan terakhir SMA adalah sebanyak 12 Orang $(30,00 \%)$, serta yang memiliki pendidikan terakhir lainnya sebanyak 4 orang yang terdiri atas 1 orang berpendidikan terakhir Strata dua dan 3 orang lainnya berpendidikan terakhir diploma.

d. Lama Bekerja Responden

Berikut adalah deskripsi lama bekerja responden

Tabel 4.4

Lama Bekerja Responden

\begin{tabular}{|ll|r|r|r|r|}
\hline & & & Valid & \multicolumn{2}{c|}{$\begin{array}{c}\text { Cumulative } \\
\text { Percent }\end{array}$} \\
\hline Valid & Frequency & Percent & Percent & \multicolumn{2}{|c|}{ 3-6 bulan } \\
1-3 tahun & 6 & 15,0 & 15,0 & 37,0 \\
& 9 & 22,5 & 22,5 & 42,5 \\
& $3-5$ tahun & 2 & 5,0 & 5,0 & 100,0 \\
di atas 5 tahun & 23 & 57,5 & 57,5 & \\
Total & 40 & 100,0 & 100,0 & \\
\hline
\end{tabular}

(Sumber: olahan penelitian 2016)

Gambar 4.4

Persentase Lama Bekerja Responden

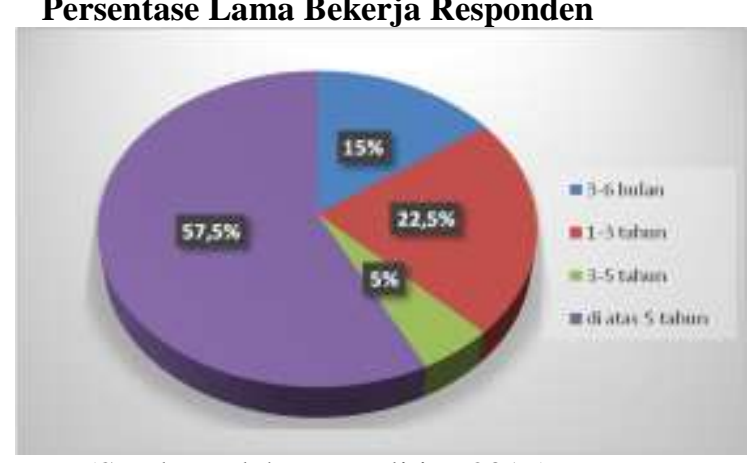

(Sumber: olahan penelitian 2016)

Berdasarkan Tabel 4.4dan Gambar 4.4 dapat dijelaskan bahwa responden terbanyak memiliki lama bekerja diatas 5 tahun yaitu sebanyak 23 orang $(57,50 \%)$, disusul dengan responden yang sudah bekerja di KPU Kabupaten Musi Rawas antata $1-3$ tahun sebanyak 9 orang $(22,50 \%)$, kemudian sebanyak 6 orang $(15,00 \%)$ responden yang telah bekerja selama 3 bulan -6 bulan dan terdapat 2 orang $(5,00 \%)$ yang telah bekerja hampir 5 tahun. 
e. Jabatan/PosisiResponden

Berikut adalah deskripsi jabatan/posisiresponden pada saat bekerja sebagai pegawai di Komisi Pemilihan Umum (KPU) Kabupaten Musi Rawas;

Tabel 4.5

Jabatan Responden

\begin{tabular}{|l|c|c|}
\hline \multicolumn{1}{|c|}{ Jabatan } & Jumlah & Persentase \\
\hline Komisioner & 5 & $12,50 \%$ \\
\hline Sekretaris & 1 & $2,50 \%$ \\
\hline Kepala Sub bagian & 4 & $10,00 \%$ \\
\hline Staf & 30 & $75,00 \%$ \\
\hline \multicolumn{1}{|c|}{ Jumlah } & $\mathbf{4 0}$ & $\mathbf{1 0 0 , 0 0 \%}$ \\
\hline
\end{tabular}

(Sumber: Hasil Kuesioner, data diolah 2016)

Gambar 4.5

Persentase Jabatan/Posisi Responden

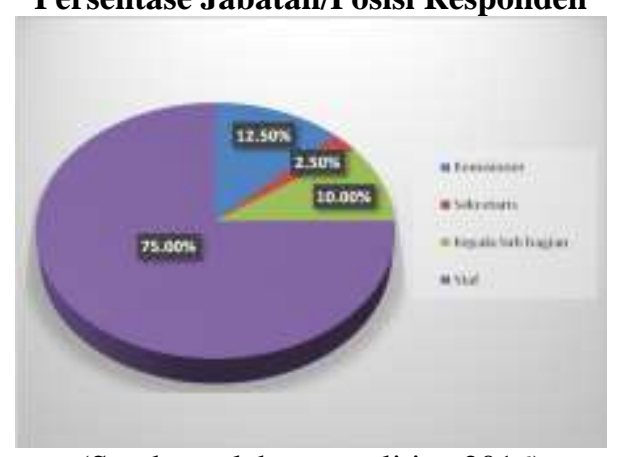

(Sumber: olahan penelitian 2016)

Berdasarkan Tabel 4.5 dan Gambar 4.5 dapat dijelaskan bahwa responden dengan jabatan sebagai Komisioner sebanyak 5 orang $(12,50 \%)$ terdiri atas 1 orang ketua dan 4 orang anggota. Sekretaris selaku Kepala Satuan Kerja sebanyak 1 orang dibantu oleh 4 orang $(10,00 \%)$ Kepala Sub Bagian yang membidangi hal - hal teknis seperti administrasi, keuangan rutin, teknis penyelenggaraan pemilihan umum baik untuk pemilihan dewan perwakilan rakyat maupun untuk pemilihan kepala daerah dan wakil kepala daerah. Jumlah responden dengan jabatan staf sebanyak 30 orang $(75,00 \%)$.

Tabel 4.6. Frekuensi Jawaban RespondenVariabel Kompensasi

\begin{tabular}{|c|c|c|c|c|}
\hline & Frequency & Percent & $\begin{array}{l}\text { Valid } \\
\text { Percent }\end{array}$ & $\begin{array}{l}\text { Cumulative } \\
\text { Percent }\end{array}$ \\
\hline $\begin{array}{l}\text { Valid } \\
1,81-2,60=\text { kompensasi } \\
\text { bernilai kurang tinggi }\end{array}$ & 2 & 5,0 & 5,0 & 5,0 \\
\hline $\begin{array}{l}2,61-3,40=\text { kompensasi } \\
\text { bernilai cukup tinggi }\end{array}$ & 8 & 20,0 & 20,0 & 25,0 \\
\hline $\begin{array}{l}3,41-4,20=\text { kompensasi } \\
\text { bernilai tinggi }\end{array}$ & 30 & 75,0 & 75,0 & 100,0 \\
\hline Total & 40 & 100,0 & 100,0 & \\
\hline
\end{tabular}

(Sumber: olahan penelitian 2016)

\section{Gambar 4.6}

Persentase Frekuensi Variabel Kompensasi 


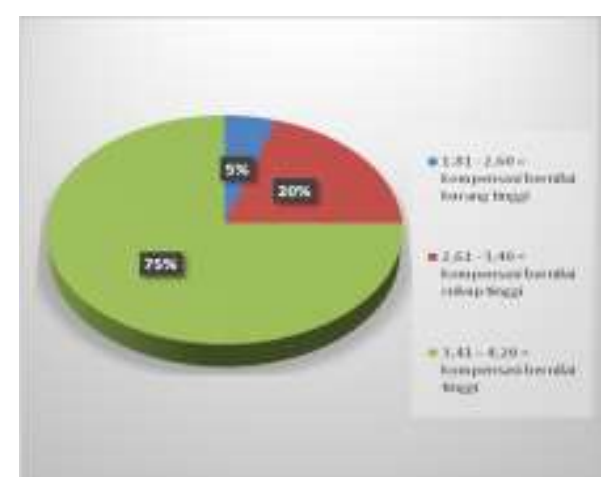

Berdasarkan Tabel 4.6dan Gambar 4.6 dapat dijelaskan bahwa responden yang menjawab kompensasi bernilai tinggi sebanyak rata - rata 30 responden $(75,0 \%)$, yang menjawab kompensasi bernilai cukup tinggisebanya 8 responden $(20,00 \%)$, sedangkan yang menjawab kompensasi bernilai kurang tinggi sebanyak 2 responden $(5,0 \%)$. Dari deskripsi ini dapat disimpulkan bahwa sebagian besar responden memberikan pendapat bahwa kompensasi memiliki peranan yang sangat penting bagi pegawai di sekretariat Komisi Pemilihan Umum Kabupaten Musi Rawas. Berikut adalah frekuensi tanggapan responden pada variabel Budaya Organisasi di Sekretariat Komisi Pemilihan Umum Kabupaten Musi Rawas:

Tabel 4.7

Frekuensi Jawaban Responden Variabel Budaya kerja

\begin{tabular}{|c|c|c|c|c|}
\hline & Frequency & Percent & $\begin{array}{l}\text { Valid } \\
\text { Percent }\end{array}$ & $\begin{array}{l}\text { Cumulative } \\
\text { Percent }\end{array}$ \\
\hline $\begin{array}{l}\text { Valid } \\
2,61-3,40=\text { Budaya } \\
\text { kerja bernilai cukup }\end{array}$ & 4 & 10,0 & 10,0 & 10,0 \\
\hline $\begin{array}{l}3,41-4,20=\text { Budaya } \\
\text { kerja bernilai Baik }\end{array}$ & 33 & 82,5 & 82,5 & 92,5 \\
\hline $\begin{array}{l}4,21-5,00=\text { Budaya } \\
\text { kerja bernilai Sangat } \\
\text { Baik }\end{array}$ & 3 & 7,5 & 7,5 & 100,0 \\
\hline Total & 40 & 100,0 & 100,0 & \\
\hline
\end{tabular}

(Sumber: olahan penelitian 2016)

Gambar 4.7

Persentase Frekuensi Variabel Budaya kerja 


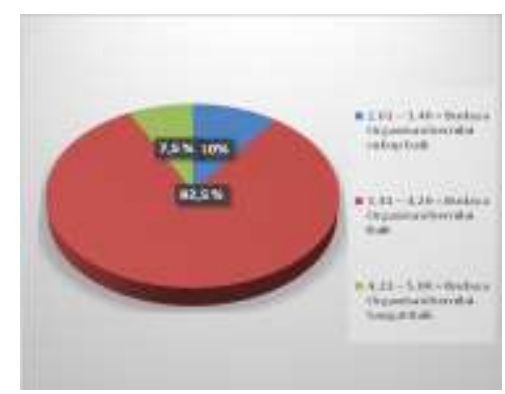

(Sumber: olahan penelitian 2016)

Berdasarkan pada Tabel 4.7dan Gambar 4.7 diketahui bahwa budaya kerja di Sekretariat Komisi Pemilihan Umum Kabupaten Musi Rawas bernilai baik dengan frekuensi jawaban sebanyak 33 (82,5\%). Sedangkan responden yang menjawab bahwa budaya kerja bernilai cukup baik sebanyak 4 (10\%) serta responden yang menyatakan budaya kerja di Komisi Pemilihan Umum Kabupaten Musi Rawas bernilai sangat baik sebanyak 3 (7,5\%). Berikut adalah frekuensi tanggapan responden variabel Motivasi Kerja Pegawai di Sekretariat Komisi Pemilihan Umum Kabupaten Musi Rawas;

Tabel 4.8

Frekuensi Jawaban Responden

Variabel Motivasi Kerja Pegawai

\begin{tabular}{|l|l|l|l|l|}
\hline & Frequency & Percent & $\begin{array}{l}\text { Valid } \\
\text { Percent }\end{array}$ & $\begin{array}{l}\text { Cumulativ } \\
\text { e Percent }\end{array}$ \\
\hline $\begin{array}{l}\text { Valid } \begin{array}{l}2,61-3,40=\text { Motivasi } \\
\text { Kerja bernilai cukup } \\
\text { tinggi }\end{array} \\
\begin{array}{l}3,41-4,20=\text { Motivasi } \\
\text { Kerja bernilai tinggi }\end{array}\end{array}$ & 17 & 20,0 & 20,0 & 20,0 \\
$\begin{array}{l}\text { 4,21 - 5,00 = Motivasi } \\
\text { Kerja bernilai sangat } \\
\text { tinggi }\end{array}$ & 15 & 32,5 & 42,5 & 62,5 \\
\hline Total & 40 & 100,0 & 100,0 & 100,0 \\
\hline
\end{tabular}

(Sumber: olahan penelitian 2016)

Gambar 4.8. Persentase Frekuensi Variabel Budaya kerja

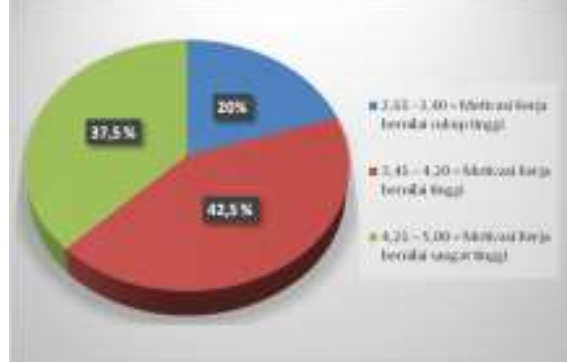

(Sumber: olahan penelitian 2016)

Berdasarkan pada Tabel 4.8dan Gambar 4.8 dapat dideskripsikan bahwa responden yang menyatakan motivasi kerja 
bernilai tinggi sebanyak 17 (42,5\%), sedangkan responden yang menyatakan motivasi kerja bernilai sangat tinggi sebanyak $15(37,5 \%)$ dan responden yang menyatakan Motivasi Kerja bernilai cukup tinggi sebanyak $8(20,0 \%)$.

\section{Deskripsi Hasil Skoring Rata - rata}

Skoring rata - rata digunakan untuk mengetahui bagaimana kondisi nyata ketiga variabel penelitian. Berikut adalah deskripsi hasil analisis kuesioner dengan menggunakan teknik skoring rata - rata untuk masing - masing variabel:

1) Variabel Kompensasi

Berikut adalah hasil analisis kuesioner dengan teknik skoring rata rata untuk variabel kompensasi pada pegawai Komisi Pemilihan Umum Kabupaten Musi Rawas (Tabel 4.9).

Tabel 4.9. Skoring Rata - RataVariabel Kompensasi

\begin{tabular}{|l|l|l|}
\hline Indikator & Rata - rata & Keterangan \\
\hline Kompensasi Finansial & 3,71 & Baik \\
\hline Kompensasi non Finansial & 3,68 & Baik \\
\hline Rata - rata Variabel & 3,69 & Baik \\
\hline \multicolumn{2}{|c|}{ (Sumber: olahan } &
\end{tabular}

(Sumber: olahan penelitian 2016)

Berdasarkan Tabel 4.9 dapat dijelaskan indikator Kompensasi Finansialmemperoleh rata - rata skor tertinggi yaitu sebesar 3.71. Hasil ini masuk dalam kualifikasi "Baik". Sedangkan indikator yang memperoleh skor rata - rata terendah adalah indikator Kompensasi non Finansialsebesar 3,68. Walaupun begitu hasil ini masih masuk dalam kualifikasi "Baik". Secara keseluruhan, skor rata - rata variabel kompensasi adalah sebesar 3,69. Hasil ini menunjukkan bahwa kompensasi yang diberikan oleh Komisi Pemilihan Umum Kabupaten Musi Rawas termasuk dalam kualifikasi "Baik".

2) Variabel Budaya kerja

Berikut adalah hasil analisis kuesioner dengan teknik skoring rata rata untuk variabel Budaya kerja pegawai di Sekretariat Komisi Pemilihan Umum Kabupaten Musi Rawas.

Tabel 4.10

Skoring Rata - Rata

Variabel Budaya kerja

\begin{tabular}{|l|l|l|}
\hline Indikator & Rata - rata & Keterangan \\
\hline $\begin{array}{l}\text { Inovasi dan Keberanian } \\
\text { Mengambil Resiko }\end{array}$ & 3,80 & Baik \\
\hline Orientasi Tim & 3,94 & Baik \\
\hline Keagresifan & 3,88 & Baik \\
\hline Rata - rata Variabel & 3,87 & Baik \\
\hline
\end{tabular}

(Sumber: olahan penelitian 2016)

Berdasarkan Tabel 4.10 dapat dijelaskan bahwa rata - rata skor tertinggi pada indikator Orientasi Timyaitu 3,94. Hasil rata - rata ini 
masuk dalam kualifikasi "Baik". Sementara untuk indikator Inovasi dan Keberanian Mengambil Resiko memperoleh skor rata - rata terendah sebesar 3,80dan hasil ini masuk dalam kualifikasi "Baik". Untuk rata rata variabel sebesar 3,87, hasil ini menunjukkan bahwa budaya kerja pegawai di sekretariat Komisi Pemilihan Umum Kabupaten Musi Rawas masuk dalam kualifikasi "Baik".

3) Variabel Motivasi Kerja

Berikut adalah hasil analisis kuesioner dengan teknik skoring rata rata untuk variabel Motivasi Kerja pegawai di Sekretariat Komisi Pemilihan Umum Kabupaten Musi Rawas.

Tabel 4.11

Skoring Rata - Rata

Variabel Motivasi Kerja Pegawai

\begin{tabular}{|l|c|l|}
\hline Indikator & Rata - rata & Keterangan \\
\hline Filosofi & 4,09 & Tinggi \\
\hline Rasa Aman & 3,79 & Tinggi \\
\hline Sosial & 4,31 & Sangat Tinggi \\
\hline Penghargaan & 3,61 & Tinggi \\
\hline Aktualisasi Diri & 4,11 & Tinggi \\
\hline Rata - Rata Variabel & $\mathbf{3 , 9 8}$ & Tinggi \\
\hline
\end{tabular}

(Sumber: olahan penelitian 2016)

Berdasarkan Tabel 4.11 dapat dijelaskan bahwa indikator Sosial memperoleh skor rata - rata sebesar 4,31. Hasil ini masuk dalam kualifikasi "Sangat Tinggi". Indikator Penghargaan memperoleh rata rata terkecil yaitu 3,61dan hasil ini masuk dalam kualifikasi "Tinggi". Secara keseluruhan, skor rata - rata variabel Motivasi Kerja sebesar 3,98 dan hasil ini menunjukkan bahwa pegawai di Sekretariat Komisi Pemilihan Umum Kabupaten Musi Rawas memiliki motivasi yang tinggi berdasarkan atas indikator - indikator yang muncul di Komisi Pemilihan Umum Kabupaten Musi Rawas.

Tabel 4.12

Coefficients $^{\mathbf{a}}$

\begin{tabular}{|l|l|l|l|l|l|}
\hline \multirow{2}{*}{ Model } & \multicolumn{2}{|l|}{$\begin{array}{l}\text { Unstandardized } \\
\text { Coefficients }\end{array}$} & $\begin{array}{l}\text { Standardized } \\
\text { Coefficients }\end{array}$ & & \multirow{2}{*}{ Sig. } \\
\cline { 2 - 4 } & B & $\begin{array}{l}\text { Std. } \\
\text { Error }\end{array}$ & Beta & T &, 960 \\
\hline (Constant) &,- 045 &, 877 & &,- 051 &, 019 \\
\hline Kompensasi &, 317 &, 130 &, 339 & $\frac{2,444}{3,003}$ &, 005 \\
\hline Budaya kerja &, 735 &, 245 &, 417 &
\end{tabular}

a. Dependent Variable: Motivasi Kerja

(Sumber: olahan penelitian 2016)

Dengan menggunakan Tabel 4.10 dapat dijabarkan rumus regeresi yaitu $\mathrm{Y}=-0,045+0,317 \mathrm{X} 1+0,735 \mathrm{X} 2$. Penjelasan dari formula ini adalah sebagai berikut: 
1) $-0,045$ adalah nilai konstanta dimana jika variabel kompensasi dan budaya kerja adalah nol, maka koefisien variabel motivasi kerja adalah sebesar $-0,045$.

2) 0,317 adalah koefisien konstanta variabel kompensasi (X1) dimana jika variabel kompensasi dinaikkan satu satuan akan meningkatkan variabel motivasi kerja sebesar 0,317. Sebaliknya, jika variabel kompensasi diturunkan satu satuan akan menurunkan variabel motivasi kerja sebesar 0,317 .

3) 0,735 adalah koefisien konstanta variabel budaya kerja (X2) dimana jika variabel budaya kerja dinaikkan satu satuan akan meningkatkan variabel motivasi kerja sebesar 0,735. Sebaliknya, jika variabel budaya kerja diturunkan satu satuan akan menurunkan variabel kompensasi sebesar 0,735 .

Tabel 4.13

Hasil Hitung Koefisien Determinasi

\section{Model Summary}

\begin{tabular}{|l|l|l|l|l|}
\hline & & & & \\
Model & $\mathrm{R}$ & $\mathrm{R}$ Square & Adjusted R Square & $\begin{array}{l}\text { Std. Error of the } \\
\text { Estimate }\end{array}$ \\
\hline 1 &, $635^{\mathrm{a}}$ &, 404 &, 371 &, 4180 \\
\hline
\end{tabular}

a. Predictors: (Constant), Budaya kerja, Kompensasi

(Sumber: olahan penelitian 2016)

Koefisien determinasi dihitung dengan mengkuadratkan Koefisien Korelasi (R). Pada table 4.13 nilai R sebesar 0,635 maka koefisien determinasi $\left(R^{2}\right)$ adalah sebesar $0,635 \times 0,635=0,404$. Berarti kemampuan variabel bebas dalam menentukan varians dari variabel terikatnya adalah sebesar 40,40\%. Dengan hasil ini dapat diketahui bahwa besaran pengaruh variabel kompensasi dan budaya kerja terhadap motivasi kerja adalah sebesar 40,40\%. Ini menunjukkan juga bahwa terdapat faktor atau variabel lain yang mempengaruhi motivasi kerja sebesar 59,60\%.

\section{Pengujian Hipotesis}

Untuk menjawab hipotesis yang diajukan digunakan uji $\mathrm{F}$ dan uji $\mathrm{t}$ parsial.Uji $\mathrm{F}$ digunakan untuk menjawab hipotesis bahwa secara bersamaan variabel kompensasi dan budaya kerja berpengaruh terhadap motivasi kerja pegawai di sekretariat Komisi Pemilihan Umum Kabupaten Musi Rawas. Uji t parsial digunakan untuk menjawab hipotesis bahwa kepemimpinan transformasional dan motivasi berprestasi secara terpisah mempengaruhi kepuasan kerja. Berikut penjelasan masing-masing hasil uji hipotesis.

\section{Hipotesis Pertama}

Hipotesis pertama menyatakan bahwa secara bersamaan maisyah dan budaya kerja mempengaruhi motivasi kerja pegawai di sekretariat Komisi Pemilihan Umum Kabupaten Musi Rawas. Berikut hasil uji hipotesis dengan rumus uji $\mathrm{F}$. 
Tabel 4.14. Hasil Hitung Uji F

ANOVAa

\begin{tabular}{|l|l|l|l|l|l|}
\hline Model & Sum of Squares & df & Mean Square & F & Sig. \\
\hline 1 Regression & 4,373 & 2 & 2,187 & 12,516 &, $000^{\mathrm{b}}$ \\
Residual & 6,464 & 37 &, 175 & & \\
Total & 10,838 & 39 & & & \\
\hline
\end{tabular}

a. Dependent Variable: Motivasi Kerja

b. Predictors: (Constant), Budaya kerja, Maisyah

(Sumber: Hasil Kuesioner, data diolah 2016)

BerdasarkanTabel 4.14, didapat bahwa nilai $F_{\text {hitung }}$ yang diperoleh adalah sebesar 12,516, sedangkan df $1=\mathrm{k}-1=3-1=2$, dan df2 $=\mathrm{n}-\mathrm{k}=$ 40-3 = 37, sehingga nilai $\mathrm{F}$ tabel yang diperoleh adalah 3,25. Dari hasil tersebut maka dapat dikatakan bahwa hipotesis yang diajukan dapat diterima karena $F_{\text {hitung }} 43,930>\mathrm{F}_{\text {tabel }} 3$,25. Hal ini menunjukkan bahwa secara bersama-sama (simultan) variabel bebas penelitian Maisyah dan budaya kerja) secara simultan berpengaruh signifikan terhadap variabel terikat (motivasi kerja pegawai) di sekretariat Komisi Pemilihan Umum Kabupaten Musi Rawas.

Pada Tabel 4.14 juga diperoleh data 'Sig.' di sini berarti taraf Signifikansi. Kriteria pengujiannya adalah apabila nilai 'Sig.' lebih kecil dari taraf signifikansi yang digunakan 0,05 dan diperoleh bahwa nilai Sig adalah 0,00 yang artinya lebih kecil dari 0,05 maka dapat disimpulkan bahwa terdapat pengaruh yang signifikan antara Maisyah $\left(\mathrm{X}_{1}\right)$ dan Budaya kerja $\left(\mathrm{X}_{2}\right)$ secara simultan terhadap Motivasi Kerja (Y) dan sebaliknya.

\section{Hipotesis Kedua}

Hipotesis kedua menyatakan bahwa Maisyah berpengaruh terhadap motivasi kerja pegawai di sekretariat Komisi Pemilihan Umum Kabupaten Musi Rawas. Berikut adalah hasil uji hipotesisnya:

Coefficients $^{\mathrm{a}}$

Tabel 4.15. Hasil Hitung Uji t Parsial

\begin{tabular}{|c|c|c|c|c|c|}
\hline \multirow[b]{2}{*}{ Model } & \multicolumn{2}{|c|}{$\begin{array}{l}\text { Unstandardized } \\
\text { Coefficients }\end{array}$} & \multirow{2}{*}{$\begin{array}{l}\begin{array}{l}\text { Standardized } \\
\text { Coefficients }\end{array} \\
\text { Beta }\end{array}$} & \multirow[b]{2}{*}{$\mathrm{t}$} & \multirow[b]{2}{*}{ Sig. } \\
\hline & B & $\begin{array}{l}\text { Std. } \\
\text { Error }\end{array}$ & & & \\
\hline 1 (Constant) &,- 045 &, 877 & &,- 051 &, 960 \\
\hline Maisyah &, 317 &, 130 &, 339 & 2,444 & ,019 \\
\hline Budaya kerja &, 735 &, 245 &, 417 & 3,003 &, 005 \\
\hline
\end{tabular}

a. Dependent Variable: Motivasi Kerja

(Sumber: olahan penelitian 2016) 
Hasil Uji - $\mathrm{t}$ parsial pada Tabel 4.15 menunjukkan $\mathrm{t}_{\text {hitung }}$ untuk variable $\mathrm{X}_{1}$ (Maisyah) sebesar 2,444, dengan derajat kebebasan $(\mathrm{df})=\mathrm{n}-2$ maka (df) adalah 40-2=38 ditemukan nilai $\mathrm{t}-$ tabel sebesar 2,02439. Hasil ini menunjukkan bahwa hipotesis pertama yang menyatakan bahwa Maisyah berpengaruh terhadap motivasi kerja pegawai di sekretariat Komisi Pemilihan Umum (KPU) Kabupaten Musi Rawas diterima karena besarnya $t_{\text {hitung }} 2,444>t_{\text {tabel }}$ 2,02439. Sehingga dapat dikatakan bahwa Maisyah berpengaruh terhadap motivasi kerja pegawai di sekretariat Komisi Pemilihan Umum (KPU) Kabupaten Musi Rawas.

\section{Hipotesis Ketiga}

Hipotesis ketiga menyatakan bahwa budaya kerjaberpengaruh terhadap motivasi kerja pegawai di sekretariat Komisi Pemilihan Umum (KPU) Kabupaten Musi Rawas. Dengan menggunakan dasar pada Tabel 4.15 dapat dijelaskan bahwa dengan derajat kebebasan $(\mathrm{df})=\mathrm{n}-2$ maka (df) adalah 40-2=38 ditemukan nilai $\mathrm{t}$ - tabel sebesar 2,02439, maka hipotesis ketiga yang menyatakan bahwa budaya kerja berpengaruh terhadap motivasi kerja pegawai di sekretariat Komisi Pemilihan Umum (KPU) Kabupaten Musi Rawas diterima karena besarnya $t_{\text {hitung }}$ 3,003(lihat Tabel 4.15) lebih besar daripada $t_{\text {tabel }} 2,01410$. Sehingga dapat dikatakan bahwa budaya kerja berpengaruh terhadap motivasi kerja pegawai di sekretariat Komisi Pemilihan Umum (KPU) Kabupaten Musi Rawas.

\section{Pembahasan}

Hasil penelitian menunjukkan bahwa adanya hubungan positif antara variabel independen (Maisyah dan budaya kerja) dengan dependen variabel (motivasi kerja pegawai). Hal ini diitunjukkan dengan hasil uji regresi linear berganda dimana nilai koefisien konstan X1 (Maisyah) dan X2 (budaya kerja) menghasilkan koefisien positif. Artinya kenaikan variabel X1 dan X2 akan searah dengan kenaikan variabel Y (motivasi kerja pegawai). Hasil analisis kuesioner dengan teknik skoring rata - rata menunjukkan bahwa Maisyah yang diberikan oleh Komisi Pemilihan Umum (KPU) Kabupaten Musi Rawas masuk dalam kualifikasi "Baik". Hasil ini menunjukkan bahwa Komisi Pemilihan Umum (KPU) Kabupaten Musi Rawas:

a. Sudah menyusun visi dan misi organisasi yang disampaikan kepada seluruh pegawai.

b. Mampu menanamkan rasa bangga kepada para pegawai bahwa mereka menjadi bagian dari organisasi KPU.

c. Mampu mengkomunikasikan cita-citanya yang tinggi kepada karyawan.

d. Mampu membangun antusiasme pegawai terhadap pertumbuhan organisasi.

e. Mampu menggunakan kultur pegawai dalam menjalin komunikasi.

f. Mampu menggunakan rasionalitas secara cermat dalam melakukan pemecahan masalah.

g. Mampu mendorong karyawan untuk memunculkan ide-ide baru dalam pemecahan masalah.

h. Memperhatikan pribadi setiap individu dalam organisasi dan menghargai perbedaannya.

i. Memberikan nasehat dan pengarahan secara kontinyu kepada pegawai. 
j. Mampu menerapkan asas keterbukaan, keseimbangan dan keadilan.

k. Memiliki cukup kemampuan dalam melakukan monitoring terhadap pelaksanaan tugas pegawai.

Hasil analisis dengan teknik skoring rata - rata menunjukkan bahwa Budaya kerja pegawai di sekretariat Komisi Pemilihan Umum (KPU) Kabupaten Musi Rawas masuk dalam kualifikasi 'Baik'. Hasil ini menunjukkan bahwa:

1. Waktu penyelesaian pekerjaan oleh pegawai terukur dan sesuai dengan beban kerja.

2. Hasil supervisi atas budaya kerja pegawai dilakukan tindak lanjut.

3. Pembagian kerja untuk setiap pegawai sudah sepenuhnya didasarkan pada kompetensi khusus yang dimiliki pegawai.

4. Komisi Pemilihan Umum (KPU) telah melaksanakan pelatihan keterampilan dalam rangka pengembangan karir pegawai.

5. Besaran gaji sudah memenuhi azas keadilan sesuai dengan beban kerja.

6. Pegawai melakukan kompetisi secara sehat.

7. Pegawai sudah didukung oleh fasilitas yang memadai untuk menunjang kinerja

Motivasi berprestasi yaitu suatu keinginan untuk berhasil, berusaha keras, dan mengungguli orang lain berdasarkan suatu standar mutu tertentu (Woolfolk; 1993). Gage dan Berliner (1992) mengemukakan bahwa motivasi berprestasi adalah untuk meraih sukses dan menjadi yang terbaik dalam melakukan sesuatu. Sedangkan menurut McClelland (dalam Dimyati \& Mudjiono 1999) mengatakan bahwa salah satu motivasi yang berperan dalam individuyaitu, motivasi berprestasi (Achievement motive). Motivasi berprestasi ini mendorong seseorang untuk mencapai keberhasilan dalam melaksanakan tugasnya dimana individu bekerja sebaik mungkin dengan usaha yang sungguh-sungguh. Hasil analisis kuesioner dengan teknik skoring rata - rata menunjukkan bahwa motivasi kerja pegawai di Sekretariat Komisi Pemilihan Umum (KPU) Kabupaten Musi Rawas masuk dalam kualifikasi 'Tinggi'. Hasil ini menunjukkan bahwa:

1. Pegawai di Sekretariat Komisi Pemilihan Umum (KPU) Kabupaten Musi Rawascenderung memilih tugas dengan derajat kesulitan yang cukup tinggi. Menurut McClelland (1987), ciri pegawai yang memiliki motivasi berprestasi yaitu merek cenderung memilih tugas dengan derajat kesulitan yang sedang, yang memungkinkan berhasil. Mereka menghindari tugas yang terlalu mudah karena sedikitnya tantangan atau kepuasan yang didapat. Mereka yang menghindari tugas yang terlalu sulit kemungkinan untuk berhasil sangat kecil.

2. Pegawai di Sekretariat Komisi Pemilihan Umum (KPU) Kabupaten Musi Rawassecara terbuka menerima hasil penilaian kinerjanya untuk memperbaiki prestasi. Berkaitan dengan ini, McClelland (1987) menjelaskan bahwa karyawan yang memiliki motivasi berprestasi lebih menyukai bekerja dalam situasi dimana mereka dapat memperoleh umpan balik yang konkret tentang apa yang mereka lakukan karena jika tidak, mereka tidak dapat mengetahui apakah mereka sudah melakukan sesuatu dengan baik dibandingkan dengan yang lain. Umpan balik ini selanjutnya digunakan untuk memperbaiki prestasinya.

3. Pegawai di Sekretariat Komisi Pemilihan Umum (KPU) Kabupaten Musi Rawassecara pribadi, bertanggungjawab terhadap proses, hasil dan 
permasalahan yang muncul dalam pekerjaannya. Dengan kondisi ini dapat dikatakan bahwa pegawai di Sekretariat Komisi Pemilihan Umum (KPU) Kabupaten Musi Rawaslebih bertanggung jawab secara pribadi pada awal kinerjanya, karena dengan begitu mereka dapat merasa puas saat dapat menyelesaikan sesuatu tugas dengan baik.

4. Pegawai di Sekretariat Komisi Pemilihan Umum (KPU) Kabupaten Musi Rawaslebih tekun dalam mengerjakan tugas, walaupun tugas tersebut lebih sulit dari biasanya.

5. Pegawai di Sekretariat Komisi Pemilihan Umum (KPU) Kabupaten Musi Rawasberkompetisi dalam mengerjakan dan menyelesaikan tugas. Kondisi ini menunjukkan bahwa pegawai di Sekretariat Komisi Pemilihan Umum (KPU) Kabupaten Musi Rawas lebih tertarik dengan tugas-tugas yang melibatkan kompetisi dan kesempatan untuk unggul. Mereka juga lebih berorientasi pada tugas dan mencoba untuk mengerjakan dan menyelesaikan lebih banyak tugas dari pada individu dengan motivasi berprestasi rendah.

Dengan munculnya Maisyah yang diberikan dengan baik dan tingginya budaya kerja pegawai dimungkinkan akan memicu motivasi kerja pegawai.

Hasil uji simultan dengan menggunakan uji $F$ dan uji t parsial dalam penelitian ini menunjukkan bahwa Maisyah yang diberikan oleh Komisi Pemilihan Umum (KPU) dan budaya kerja berpengaruh secara signifikan terhadap motivasi kerja pegawai di sekretariat Komisi Pemilihan Umum (KPU)Kabupaten Musi Rawas.

\section{Simpulan}

Berdasarkan pada hasil penelitian dan pembahasan, penelitian disimpulkan bahwa Maisyah dan budaya kerja secara simultan berpengaruh terhadap motivasi kerja pegawai di sekretariat Komisi Pemilihan Umum (KPU) Kabupaten Musi Rawas, Maisyah berpengaruh terhadap motivasi kerja pegawai di sekretariat Komisi Pemilihan Umum (KPU) Kabupaten Musi Rawas, dan Budaya kerja berpengaruh terhadap motivasi kerja pegawai di sekretariat Komisi Pemilihan Umum (KPU) Kabupaten Musi Rawas. 


\section{DAFTAR PUSTAKA}

Arikunto, Suharmi, 2010, ProsedurPenelitianSuatuPendekatanPraktek Edisi Revisi. Jakarta. PT.Rineka Cipta.

Astuti, Puji. 1995. Analisis Kepemimpinan dalam Pembentukan Budaya Perusahaan di Hotel Ambarukmo. Yogyakarta. Laporan Intership MM UGM.

Anwar Prabu Mangkunegara. 2013. Manajemen Sumber Daya Manusia dan Perusahaan.Bandung: Rosda.

Badeni. 2014. Kepemimpinan dan Perilaku Organisasi. Bandung: Alfabeta.

Bahri, Syamsul. 2014. Model Penelitian Kuantitatif Berbasis SEM-AMOS. Yogyakarta. Deepublish.

Efendi, Sofian dan Tukiran. 2012. Metode Penelitian Survei. Jakarta. LP3ES.

Fahmi, Irham. 2014.Manajemen Teori, Kasus dan Solusi. Bandung.Penerbit Alfabeta.

Hanggraeni, Dewi. 2012.Manajemen Sumber Daya Manusia. Jakarta. Lembaga Penerbit FEUI.

Halimatusyadiah. 2003. Pengaruh antara gaya kepemimpinan dan Budaya Organisasi Terhadap Komunikasi dalam Tim Audit. Surabaya. Simposium Nasional Akuntansi Ke VI. Sesi IV.

Hasibuan, Malayu. 2014.Manajemen Dasar, Pengertian dan Masalah. Bandung. Bumi Aksara.

Koesmono, H Teman. 2005. Pengaruh Budaya Organisasi Terhadap Motivasi dan Kepuasan Kerja serta Kinerja Karyawan pada Sub Sektor Industri Pengolahan Kayu Skala Menegah di Jawa Timur. Jurnal Manajemen dan Kewirausahaan Volume 7 Nomor 2 September 2005.Mangkunegara, Anwar Prabu. 2010. Evaluasi Kinerja. Bandung. PT Refika Aditama.

Moeheriono. 2012. Pengukuran Kinerja Berbasis Kompetensi. Jakarta: Rajawali Pers.

Nasution, Willy Abdillah \& Farantoro. 2013. Pengaruh Motivasi Kerja, Komitmen Organisasi dan Lingkungan Kerja terhadap Kinerja Pegawai. Jurnal Ilmiah Manajemen Volume 15 Nomor 5 Oktober 2013.

Nasution, Ridwan Nuraji \& Media Septidira. 2013. Pengaruh Motivasi. Kepemimpinan dan Budaya Kerja terhadap Kinerja Pegawai. Jurnal Ilmiah Manajemen Volume 15 Nomor 5 Oktober 2013 
Praningrum. 1997. KepemimpinandanBudayaOrganisasi Usaha Batik Kecil di Yogyakarta. Yogyakarta. Laporan Intership MM UGM.

Praningrum, Darmansyah\& Dosi Elyana. 2013. Pengaruh Empowerment, Budaya Organisasi dan Organisasi Pembelajar Terhadap Kinerja Pegawai Lembaga Penjamin Mutu Pendidikan Provinsi Bengkulu. Jurnal Ilmiah Manajemen Volume 15 Nomor 5 Oktober 2013.

Republik Indonesia. 2008. Peraturan Komisi Pemilihan Umum Nomor 22 tentang Susunan Organisasi dan Tata Kerja Sekretariat Komisi Pemilihan Umum (KPU). Jakarta.

Riyadi, Slamet. 2011. Pengaruh Kompensasi Finansial, Gaya Kepemimpinan, dan Motivasi Kerja Terhadap Kinerja Karyawan pada Perusahaan Manufaktur di Jawa Timur. Jurnal Manajemen dan Kewirausahaan Volume 13 Nomor 1 Maret 2011.

Salim, Muhartini, Effed Darta Hadi \& Muharam Jaya. 2013. Pengaruh Remunerasi Terhadap Motivasi dan Kinerja Pegawai Institusi Kementrian Keuangan. Jurnal Ilmiah Manajemen Volume 15 Nomor 5 Oktober 2013.

Sindi Larasati dan Alini Gilang. 2014. Pengaruh Motivasi Kerja Terhadap Kinerja Karyawan Wilayah Telkom Jabar Barat Utara (Witel Bekasi). Bandung.Fakultas Komunikasi dan Bisnis Universitas Telkom Bandung.

Siagian, Sondang P. 2014.Manajemen Sumber Daya Manusia. Jakarta. Bumi Aksara.

Sunyoto, Danang. 2015.Manajemendan Pengembangan Sumber Daya Manusia Indonesia. Yogyakarta. CAPS.

Suwatno. 2014. Asas-Asas Manajemen Sumber Daya Manusia. Bandung.Penerbit Suci Press.

Triton PB. 2010.Manajemen Sumber Daya Manusia Indonesia. Yogyakarta. Oryza.

Uha, Ismail Nawawi. 2015. Budaya Organisasi, Kepemimpinan, dan Kinerja. Jakarta: Raja Grafindo.

Wibowo. 2013. Budaya Organisasi, Sebuah Kebutuhan Untuk Meningkatkan Kinerja Jangka Panjang. Jakarta: Raja Grafindo.

Wibowo. 2014. Manajemen Kinerja. Jakarta. Rajawali Pers.

(https://jdih.kpu.go.id/ diakses tanggal 10 Juni 2016) 